\title{
TIMBER REINFORCEMENTS: LOCAL COSTRUCTION TECHNIQUES IN ITALIAN HISTORICAL BUILDINGS
}

\author{
STEFANO DELLA TORRE AND LORENZO CANTINI
}

\author{
Dept. of Architecture, Built environment, Construction engineering (DABC) \\ Politecnico di Milano \\ Piazza Leonardo da Vinci 32, 20133 Milan, Italy \\ e-mail: stefano.dellatorre@polimi.it, www.polimi.it \\ email: lorenzo.cantini@polimi.it, www.polimi.it (*corresponding author)
}

Keywords: Historical Structure, Masonry, Monitoring, Non-Destructive Inspection

\begin{abstract}
The role of timber connections as reinforcement for vertical masonry walls is well known but still requiring a systematic study. Considering the main sources coming from the architectonic treatises, a real identification of the use of wooden poles as binding elements between walls is not recognized. Several important authors belonging to the $15^{\text {th }}$ and $16^{\text {th }}$ century recommended avoiding the use of timbering elements into the section of the walls, arguing that the perishability of this material cannot provide a long durable solution. Nevertheless, since the $17^{\text {th }}$ century also some indications from the so called "high knowledge" seem to identify a reliable technique in the timber reinforcements for masonry walls. This work explores the contraposition between theoretical approaches and the building site practice, focusing on the mechanical function of orthostatic timbers inserted into masonry structures. Recent contributions based on archive studies indicated that the use of wooden reinforcements was widely diffused in Italy, but rarely documented by the architectural theorists. The technical documentation discovered into archives is instead a rich source of information concerning the persistence of timbers inside walls as a solution against the vulnerability of masonry structures to shear forces. The case of the building site documentation for the realization of Volpi Palace in Como offers an important occasion for improving the studies on a building practice that did not meet official credits by the theoretical experts in architecture.
\end{abstract}

\section{INTRODUCTION}

Defined as a creative process produced by the mutual influences among strictly connected entities, the idea of coevolution can be applied to the rich panorama of the historical building techniques for interpreting the realization of peculiar construction solutions. Wooden elements used for improving the common connection system among masonry elements, like vertical walls and masonry arches and vaults, are an example of an upgrade required by those structures showing forms of vulnerability interacting with the environment [1].

Referring to historical buildings, local construction solutions represent the response to technical demands appeared in different times for facing specific problems, from common state of stress distribution in masonry structures to seismic mitigation. The introduction of wooden elements into masonry walls, for instance, is a widely diffused measure for reinforcing stone or 
brickworks [2]. These connections, inserted into the masonry walls, were identified by Vitruvius' treatise, as orthostatic timbers, considering the version edited by C. Cesariano. The peculiar vulnerability of masonry structures to shear stresses required such reinforcements. In Italy, after recent earthquakes (L'Aquila 2009 and Amatrice 2016), the rediscovery of such building techniques, in some cases belonging to a sort of forgotten world of knowledge, drove to design alternatives and more sustainable retrofitting interventions for historical buildings [3].

The authors, with the aim to improve the attention on these construction solutions, focused on the rich contributions contained in the historical treaties of the Italian building tradition and on some archive documents describing original design for reinforcing elements [4]. Among the various materials, the study proposes the analysis of some specific contests: Como Lake in Lombardy and the regions that in the past were under the control of the Vatican State or the Kingdom of the Two Sicilies, where this technology, based on tie beams and hut-oriented diaphragms, improved the mechanical properties of the buildings.

\section{MASONRY BUILDINGS AND WOODEN REINFORCEMENTS}

The vulnerability of historical masonry structures is an issue that becomes always prior especially after seismic events. The use of wooden frames as mitigation techniques against seismic actions was codified since the $18^{\text {th }}$ century for local situations (as in Naples kingdom). In the rich theoretical tradition about architecture, the Italian theorists did not reserve a peculiar role for the timbering elements used as reinforcing supports for masonry structures. In some cases, authors are considering the use of wooden elements into the masonry walls as a technical mistake. This assumpti timber elements into the apparent conflict betwe culture" contained in the the use of timber elentent

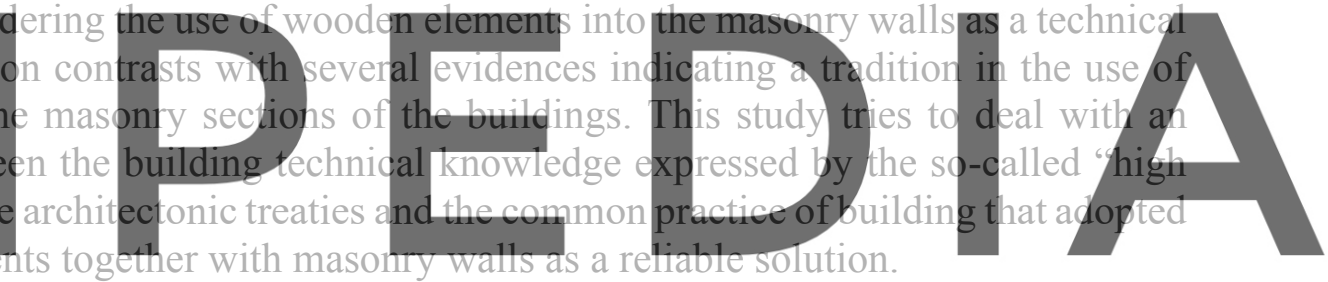

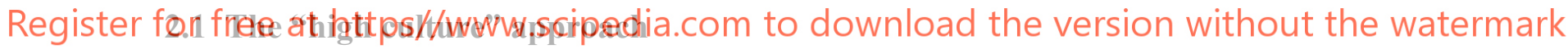

The use of timber elements into the section of masonry walls was observed in several archaeological campaigns on historical buildings. Even during restoration works, the traces of wooden elements into cavities arranged in the masonry section of the walls testified the common application of wooden reinforcements into the masonry apparatus. A first important reference for this technical solution comes from the treaty De Architectura written by Vitruvius. In the edition translated in Italian by C. Cesariano in 1521 [5], the insertion of timber into the section of the walls is described as "orthostate", a technique used for improving the connection between the walls and more in general the box-like behavior of the buildings. In the $8^{\text {th }}$ chapter of the second book of his illustrated edition, Cesariano offers a representation of some masonry typologies. The sketches at page 39 of the second book (see figure 1), referred to sepulchral monuments, show the transversal connections for masonry walls with large sections: the use of metal anchorage for linking the stone blocks is clear, but also vertical wooden elements are here represented along the edges of the structures. This chapter of the De Architectura treaty contains also the comments provided by Cesariano to its illustrations and, more than in the sketches, the role of metal or wooden connections is emphasized in his description. Respect to other theorists that will follow during $16^{\text {th }}$ and $17^{\text {th }}$ century, Cesariano did not denigrate the timber material as 
a cheap alternative to the more expensive use of metal reinforcements. He recalled the building tradition of empty cavities arranged into the masonry walls in order to be used for placing transversal connectors, which could be made by wood or metal material. Both materials were able to provide the tie effect to the stones, according to the author.

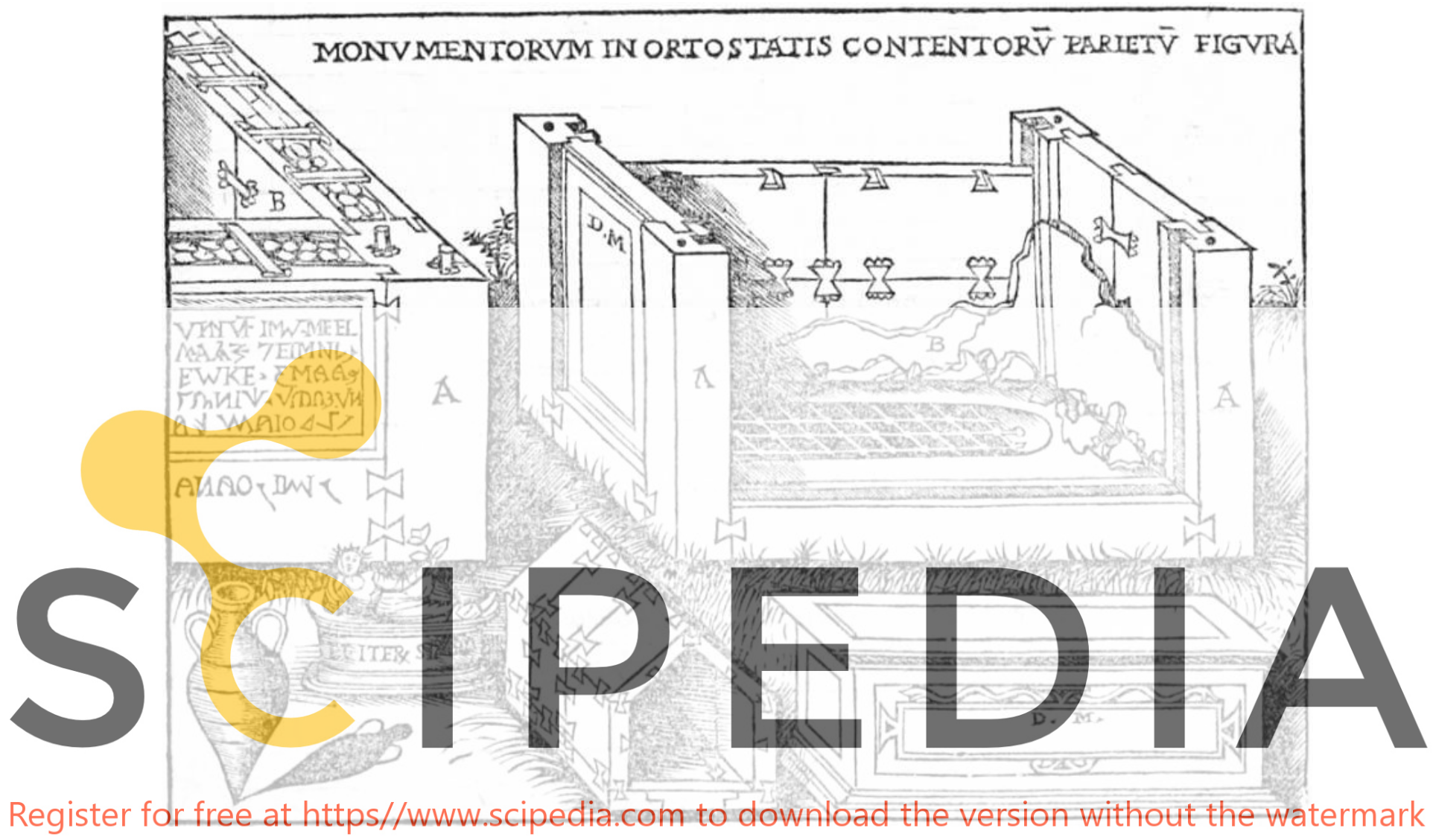

Figure 1: illustration to the Vitruvius' De Architectura issued by Cesariano (page XXXIX of the second book) in 1521. Letters A and B identify the position of wooden or metal connections inserted in the masonry structure.

The building tradition maintained the use of the tie beams into the masonry structures as documented by Viollet Le Duc for the monuments dated back to Merovingian and Carolingian era in France [6]. The linking function of the timber elements inserted in the walls is underlined by the author that in the first chapter of the Dictionnaire, about the principles of Gothic architecture, describes the mechanical logic of the masonry structures used in the Medieval cathedrals. Respect to the Romans' tradition mentioned by Vitruvius, the masonry apparatus of Gothic buildings was composed by rabble materials contained into an external layer of wellshaped stones. No cavities were here arranged for hosting timber elements, but wooden beams were inserted into the chaotic core of these structures with a fundamental role: the reinforcement of the connection between the main joints of the masonry structures, as for longitudinal walls and pillars (see figure 2a). He also stated that the long timbers inserted into the masonry at the springs of the vaults had a stabilizing and linking function in the constructive logic addressed to a reliable containment of the thrust effects generated by the masonry vaults (see figure $2 \mathrm{~b}$ ). 

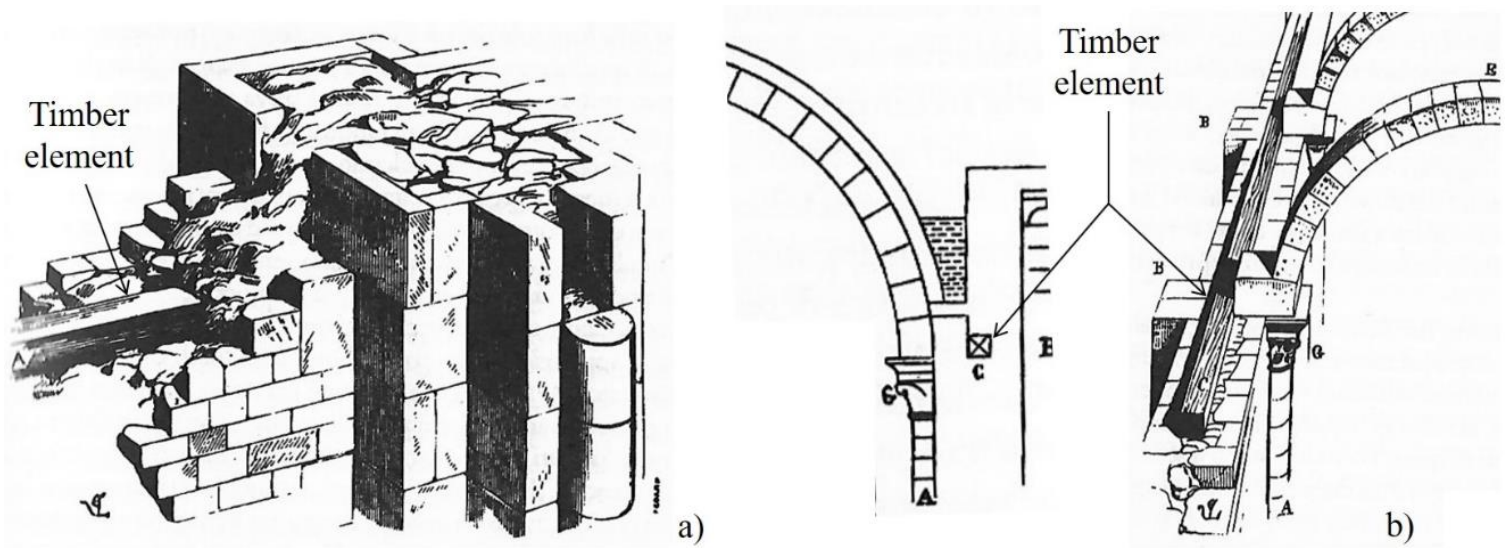

Figure 2: drawings from the Dictionnaire raisonné de l'architecture française $d u$ XI au XVI siècle by Viollet le Duc. Use of timber reinforcements in Mediaeval architecture: a) timber connection into a masonry section (from picture 2 of the Dicionnaire [6], elaborated by the authors); b) timber link for the masonry support of the wall (from picture 3 of the Dictionnaire [6], elaborated by the authors).

The structural role of timber elements integrated into masonry walls, described by Violletle-Duc in the $19^{\text {th }}$ century, comes after a long period characterized by a negative opinion concerning the use of wooden materials as reinforcement material for the walls, stated by several important theorists. L. B. Alberti, S. Serlio and later Palladio, following the setting of Vitruvius' treatise, reserved detailed descriptions about wooden structures and the preparation of the material before construction categories contrasting shear forces, should be realized b masonry apparatus, reinforcements realized by timber structures a
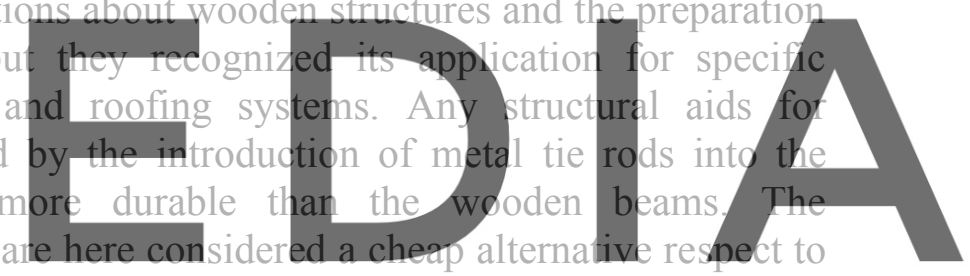

the more expensive, but more proper, technique based on metal chords crossing the section of

Register fore freelsat https//www.scipedia.com to download the version without the watermark

Among several negative opinions, V. Scamozzi, in the $9^{\text {th }}$ book of his treatise on the "universal architecture" [7], offers a description of the reinforcement aids introducing the masonry vaults, indicating both metal and wooden connections as reliable solutions. He states that timber elements request more attentions, due to the nature of the material, recommending a proper displacement near masonry structures, but not inside their sections. As an example, he mentioned the case of the cupola built by Brunelleschi for S. Maria del Fiore in Florence, where e retaining ring made by timbering system is placed at the base of the structure, in the open space between the internal and the external dome. As pointed out by Di Teodoro in [8] and Ottoni in [9], since the realization of the Florentine dome, F. Brunelleschi addressed his efforts to solve the problems connected to the discontinuities created by the octagonal geometry of the cupola. The insertion of the chain in chestnut (the "catena dei castagni") at the base of the dome (Figure 3), close to the drum, anticipated the further debate on the reinforcements requested by masonry domes and prefigured the passage from the building competences based on empirical knowledge to the more scientific analytical approach that will characterize the studies of the $17^{\text {th }}$ and the $18^{\text {th }}$ century. The builders of the $15^{\text {th }}$ century could not be supported by the studios coming from the modern solid mechanics, but the empirical experience matured on domes and vaults raised to the topic of the improvements needed by vertical masonry walls connected to 
those structures. The awareness of Brunelleschi over the thrusting effects of his dome is still discussed by the experts [8,9], but the reinforce obtained by the wooden ring inscribed into the internal and the external dome of the Florence Cathedral has two main effects:

- $\quad$ supporting the linkage between each masonry segment of the dome and the main angular ribs:

- contrasting the elastic deformation imposed by the increasing load of the structure during its realization and induced by the low hardening process of the mortar joints composing the brickwork.

The use of timber elements for improving the connections between perpendicular walls at the level of other thrusting structures, like the dominical cross vaults of Santa Maria Novella (dated back to 1355), testifies the attention to the mechanical problems deriving from the interaction between masonry walls and masonry vaults. Instead of using metal tie rods, in this case diagonal timbers were placed at the extrados of the vaults, between the perpendicular walls of each span containing the vaults, in order to create a sort of tension ring effect around them.

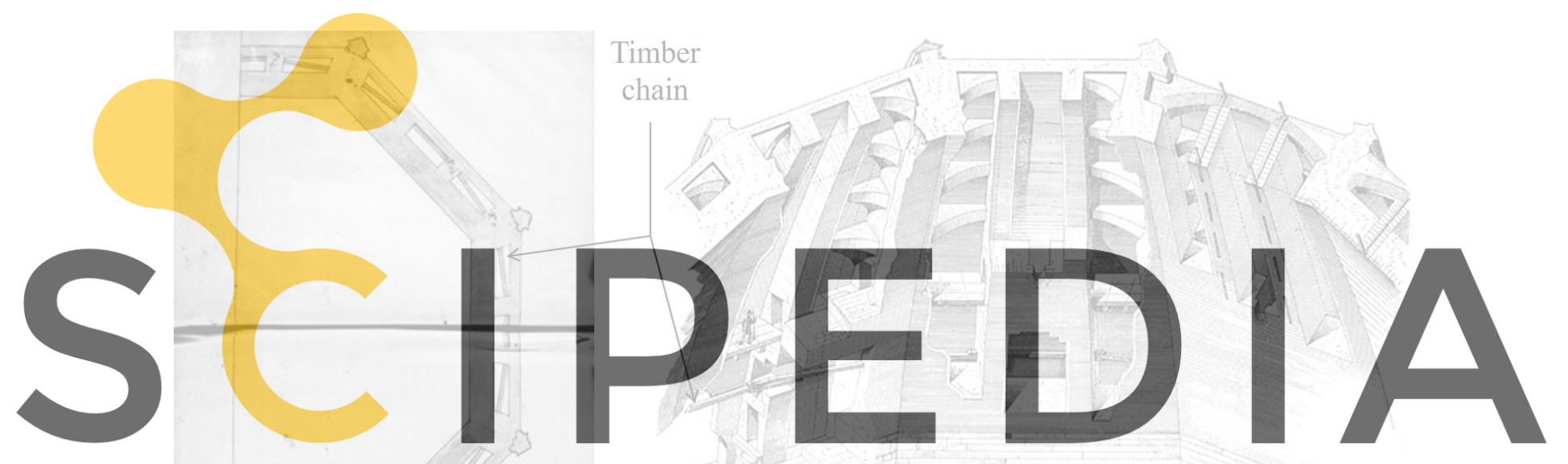

Register for free at https//www.scipedia.com to download the version without the watermark

Figure 3: The wooden chain realized around 1420 at the base of the dome by Brunelleschi: a) archive drawing published in [9], p. 159 and b) the constructive system of the dome (from Margani L. Archi e volte in muratura, Caltanissetta: Lussografica edizioni, 2009).

Even if the use of wooden reinforcements is documented in outstanding historical buildings, the peculiar attentions requested by wood material was considered a limit for its application in civil engineering. At the beginning of the $20^{\text {th }}$ century, S. Mastrodicasa, whose treatise on the mechanical behaviour of masonry buildings [10] produced an important impact on the construction field, referred to the presence of timbering systems into masonry walls as an "anomaly". A revaluation of the role of such structures had to come from other studies matured in occasion of recent seismic events, with new analysis of wooden reinforcements observed into the masonry structures of damaged buildings. 


\subsection{The "on-site practice" approach}

The use of timber elements into masonry structures is commonly accepted as a cheap alternative to the use of the more expensive metal tie-rods. As anticipated in the previous paragraph, theorists considered the use of reinforcements made of wood as a deviant solution from the so-called "good practice". Changing the perspective from theoretical field to the construction practice, the continuous research of strategical solutions for ensuring a global equilibrium, among the structural components of the building, required the utilization of timber elements. The constructive tradition based on timber-frames widely diffused in Central and North Europe was not largely adopted in Italy, but the presence of wooden ties and reinforcing timbering continued to be applied in masonry buildings. Several examples were recently documented by different studies developed in Central Italy, where the last seismic events renewed the attention to the use of timbers as preventive measure against the earthquake effects.

M. D'Antonio in [11] offers a detailed description of the wooden elements inserted in the masonry walls, adopted in Abruzzo Region. The so-called "radiciamenti" (literally "rooting systems") are wooden beams placed in the wall section at different levels along the vertical structure. Their function is a reinforce able to constitute a linkage for the masonry apparatus. These "radiciamenti" can be inserted transversally into the wall, in order to connect the different layers forming the masonry section, or longitudinally, for reinforcing the wall against flexural stress and for improving the connection in the corners (Figure 4a), if jointed by metal carpentry with another perpendicular timbers. By the inspections carried out after the 2009 L'Aquila
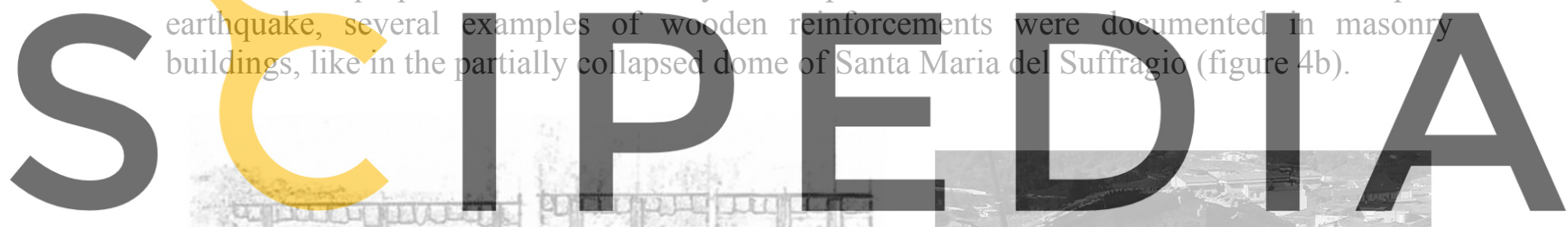

Register for free at https//www scipedia.com to download the version without the watermark

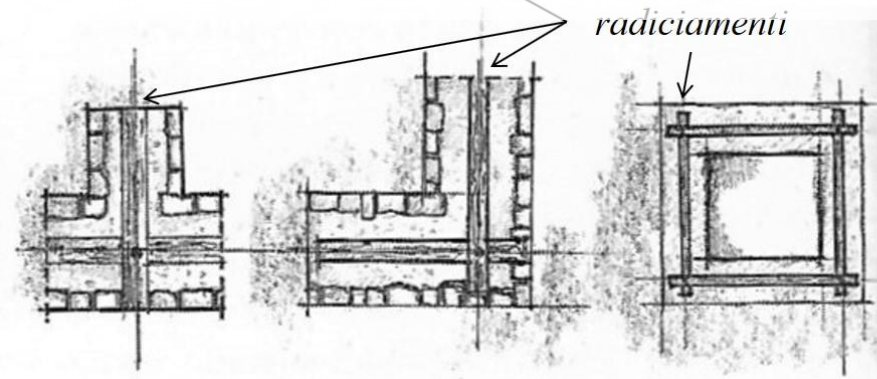

a)

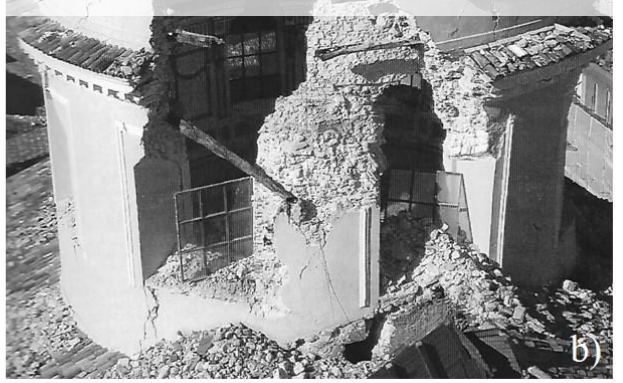

Figure 4: The wooden anti-seismic technique diffused in L'Aquila, known as "radiciamenti": a) wooden frames with different structural functions and b) the 3 orders of "radiciamenti" visible in the partially collapsed dome of Santa Maria del Suffragio hit by the 2009 L'Aquila earthquake (source from [11], pp. 27 and 52).

The frequent use of timbers into masonry walls was documented also by other studies [12, $13,14]$ carried out in Central Italy. The analysis on the masonry quality of the walls, often characterized by multiple leaf sections with chaotic rubble materials in the core, underlined a 
problem connected to the lack of resources that required the use of wooden beams for a general improvement of the masonry properties. Independently from the seismicity of the territory, the building technologies observed over the entire Italian territory showed this common feature: the recourse to timbering systems supporting the masonry apparatus. The wooden elements could be limited or inserted with a certain regularity along the vertical development of the walls, displaced inside the section or organized along its borders (Figure 5a and 5b), but in the various regional declinations, this technology supplied to the intrinsic vulnerability of masonry structures realized with poor materials. The same studies testify the diffusion of the wooden reinforcements also as preventive aid for contrasting the lateral thrust of masonry vaults and domes, as represented in the reconstruction of the timbering system surrounding the dome of San Giovanni Battista church in Penne (Pescara), reported in figure $5 \mathrm{~b}$.
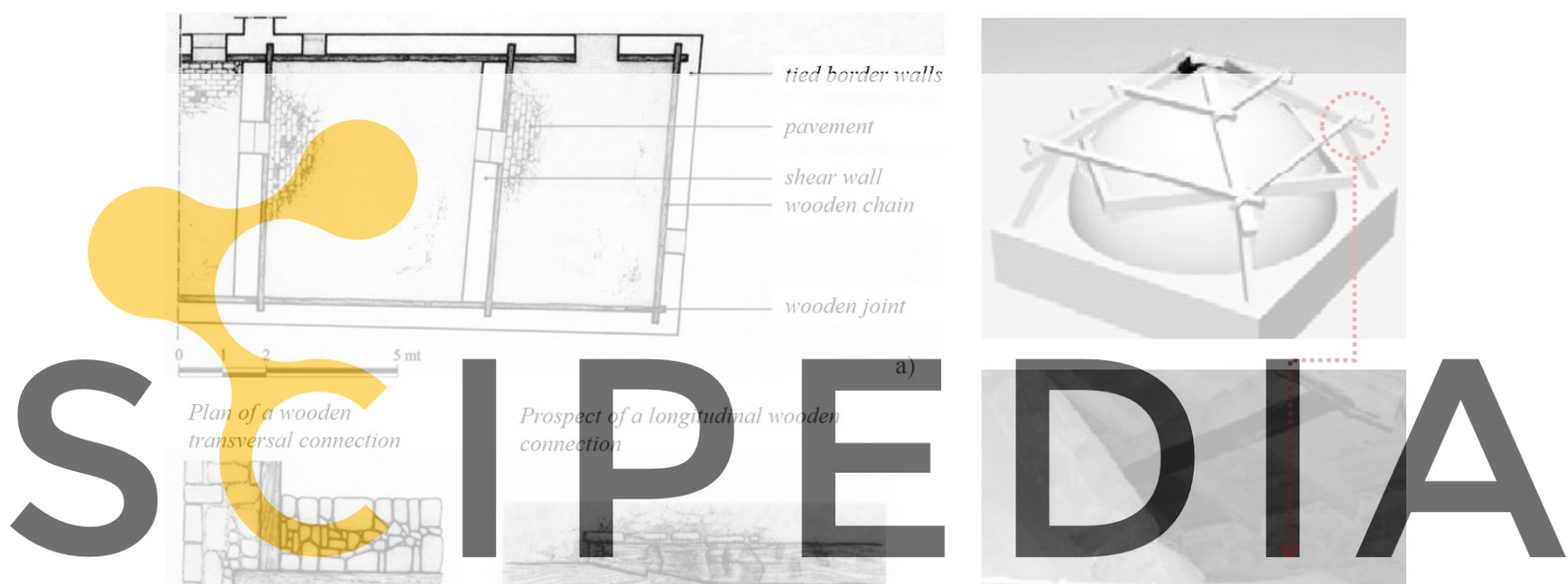

Register for free at https//www.scipedia.com to

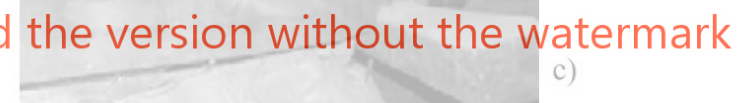

Figure 5: Tie beams: a) historical masonry building in Guardiagrele (Chieti) with improving connection between the walls (survey by E. Candigliota and published in [12], p. 16, modified by the authors); b) two details of transversal and longitudinal connections; c) the extrados of a dome in Penne with the layout of the timbering system realized for containing the lateral forces, with a picture (source in [13], p. 62, modified by the authors).

These bindings solutions are also present in Italian areas where earthquakes have a minor impact, demonstrating that the on-site practice assumed the wooden reinforcements as a reliable solution. As remarked by several authors, the building techniques based on the multiple leaf masonry typologies, belonging to the Italian constructive tradition, maintained a long-lasting relationship with timber aids. A sum of this technical knowledge about the application of reinforcements in opposition to the intrinsic vulnerability of masonry structures is provided by Pellegrino Tibaldi, one of the most influential architect of the second half of the $16^{\text {th }}$ century [14], active before in Rome and later in Milan. In his treaty (L'architettura, remained unpublished until 1990), he pointed out that the wooden floors, although not providing lateral thrusts to the walls in normal conditions, were often connected by metal tie rods and even 
integrated by timber linkages (named "ligamento", literally "tying beam") inserted into the masonry and more rarely by metal tie rods. These reinforcements had to improve the mechanical behaviour of the building that could be simplified to a box-like behaviour. Aware of the fact that wooden materials are subjected to a limited durability if confined into the wall sections, Tibaldi provided also the indications for the preliminary preparation of the material, stating that a general benefit to the stability of the building could be obtained by the use of "legno biusciato", interpretable as "burnt wood" in authors' opinion (but other experts suggested a different interpretation, translating it as "debarked wood") applied into the walls for each order of room, connected to the heads of the roofing timbers or to the springs of the vaults. This description gives a new perspective to the state of the art of the building modalities diffused in North Italy at the end of the $16^{\text {th }}$ century, where a consolidated methodology seems to be based on the common use of timber structures strictly connected to the masonry elements.

\section{RECENT CONTRIRUTES FROM SEISMIC AREAS}

The presence of timber frames applied into masonry walls for reinforcing their ligature and for implementing their deformability is widely documented in Central and South Italy. From an historical point of view, the Kingdom of Naples produced important laws and studies for the post-seismic reconstruction on different areas of its territories hit by seismic events, like Calabria and Sicily. The active support provided by timber-frames set into the masonry walls was codified after important seismic events occurred in the $18^{\text {th }}$ century in Lisbon (1756) and Calabria (1783). The large destruction left by those earthquakes led to the introduction of ney constructive principles anti-seismic typologias the vertical walls, orga and horizontal joists. In in the village of Casamicciola, a village rebui
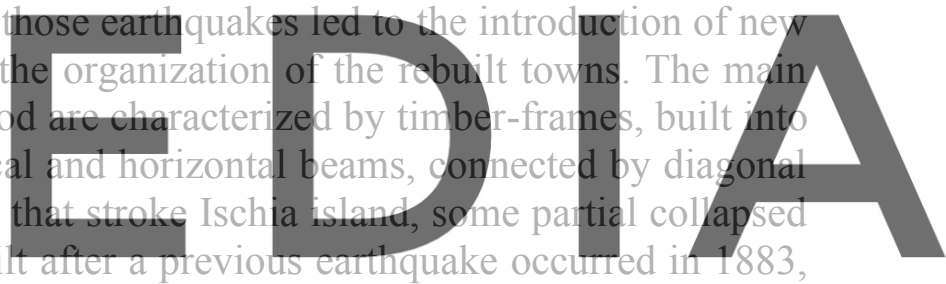
showed the recourse of such reinforcement technique for the common buildings (figure 6). The

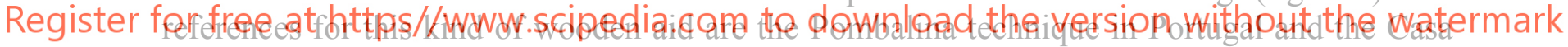
Baraccata in Calabria Region.

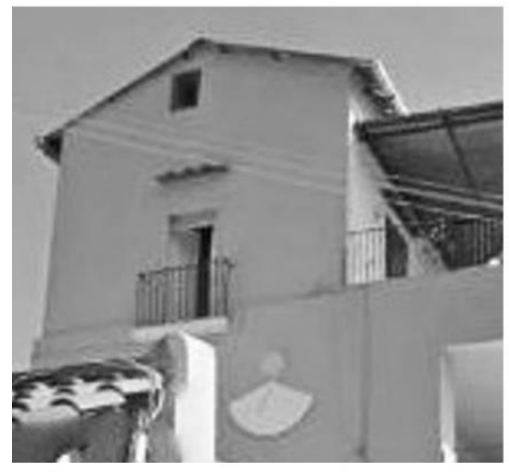

Before August 2018

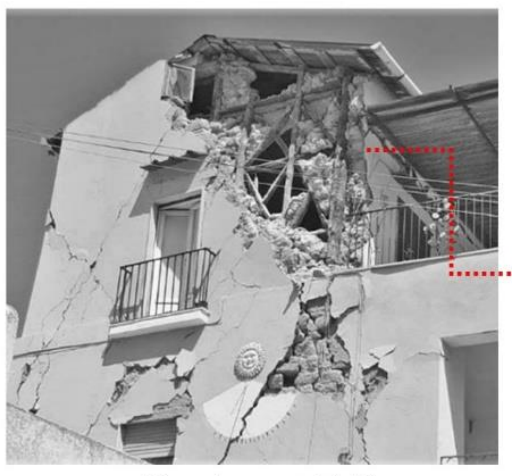

After August 2018

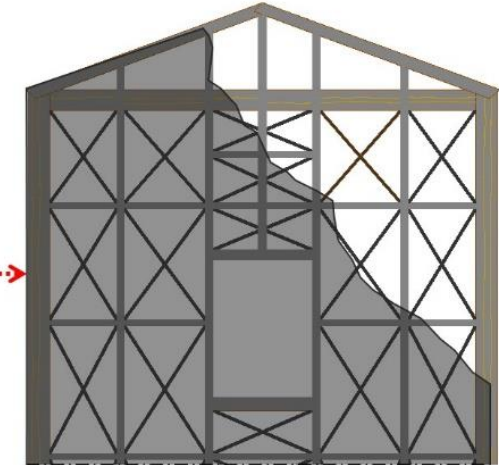

Timber-frame layout interpretation

Figure 6: A timber-frame realized in a masonry wall of a house hit by the 2018 Ischia earthquake (representation realized by the authors). 
If the intensity of the damages of some seismic events created the conditions for the formation of the so-called local seismic culture, with the preparation of specific measures for improving the buildings, it is also known that the long periods from an earthquake to another, sometimes with low magnitudes, did not contribute to maintain alive these technical solutions. The large amount of damages occurring to the built heritage in seismic areas are mainly due to the discontinuous application of the reinforces introduced immediately after the earthquakes and later abandoned when the perception of the risk becomes a far memory of past times.

The sensibility to the vulnerability of masonry structures to horizontal stresses, matured in Central and South Italy, traditionally more subjected to earthquakes respect to the North, supported the use of wooden aids with the masonry structures. As shown in the recent study set by C. Bartolomucci [15], a form of resilience can be recognized in the historical set of measures applied in important architectures belonging to a city subjected by several earthquakes like L'Aquila. Here, historical palaces are the result of a complex modification of the structures, realized in origin without the proper preventive measures for facing the seismic actions, later modified with peculiar solutions, able to contrast the telluric strains. Among them, the realization of light timber vaults, the connections between flooring systems and vertical walls by metal tie rods and the use of timber-frames into the walls introduced during the realization of some additions (see figure 7)
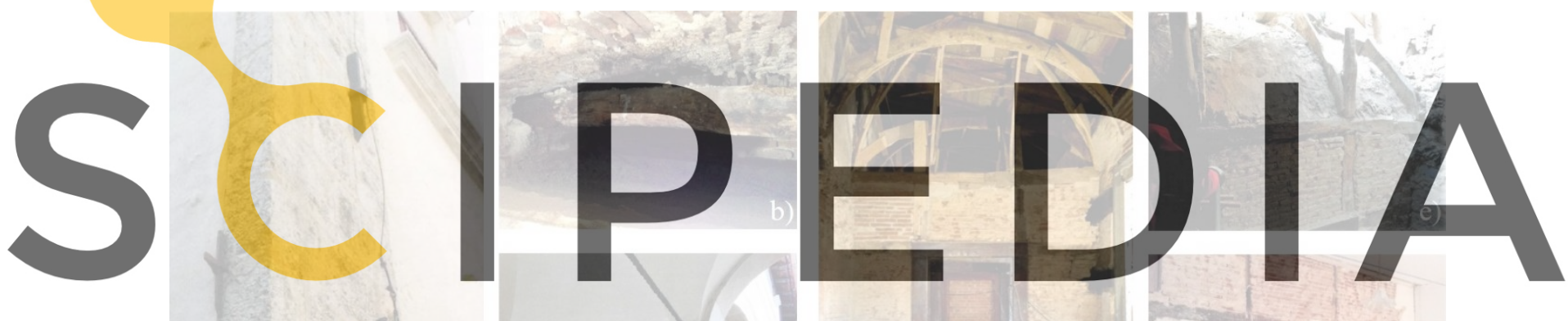

Register for free at https//www.scipedia.com to download the version without the watermark 4.
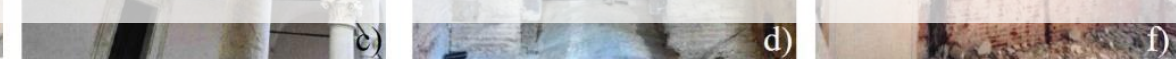

Figure 7: Anti-seismic measures adopted in Carli Benedetti Palace in L'Aquila: a) heads of the metal tie rods connecting vertical walls to horizontal structures; b) timber (radiciamento) reinforcing a masonry wall, connected to a metal tie rods crossing a chimney flow; c) tie rods at the intrados of the arches of the porch; d) the $18^{\text {th }}$ century additions composed by wooden frames, directly connected to e) the wooden reinforcements of the vaults, forming a box-like devise with $\mathrm{f}$ ) the vertical partitions (pictures from [15] elaborated by the authors).

The same consolidated culture based on the use of wooden reinforcements for masonry load bearing walls and partitions is also characterizing the building technology of the $18^{\text {th }}$ and the $19^{\text {th }}$ century in the Kingdom of Naples [16, 17]. Examples coming from Naples and Palermo demonstrate the attention of the designer addressed to anti-seismic preventive measures and the problems concerning thrusting structures. The large use of vaulted ceiling in monumental palaces and churches build in Baroque age and the experiences matured with the domes from the archetypes of Santa Maria Novella in Florence and St. Peter in Rome contributed to keep attention on wooden and metal reinforcements. 


\section{THE ARCHIVE DOCUMENTS ABOUT VOLPI PALACE IN COMO}

The long-lasting tradition of beam systems systematically applied to masonry structures is also testified by the technical drawings realized for the project of an important palace in Como, during the first half of the $17^{\text {th }}$ century. Volpi Palace had to become the residence of Volpiano Volpi, an important ecclesiastic that matured relevant assignments also in Rome [18].

The project was developed by Sergio Venturi, an architect from Siena, active in Rome at the court of Pope Paolo V. The on-site activities for the building of the palace were based on an intensive epistolary exchange between the designer, in Rome with Volpi, and the local builders.

Among the various technical aspects described in the letters, some technical drawings contain important information concerning the building technique proposed for the realization of the main representative rooms set at the ground floor of the palace. All the rooms are characterized by cloister vaults (figure 8a), a typology largely diffused in Baroque age and also known for the high lateral forces transmitted to the supporting walls. The document showing the plan of the ground floor with the vaults presents interesting details: the setting of the wooden carpentry is displayed along the masonry walls, with the timbers centered in the middle of the section, and wooden joists are also arranged at the corner of each room for providing a tension ring effect around the extrados of the vaults (figure $8 \mathrm{~b}$ ).
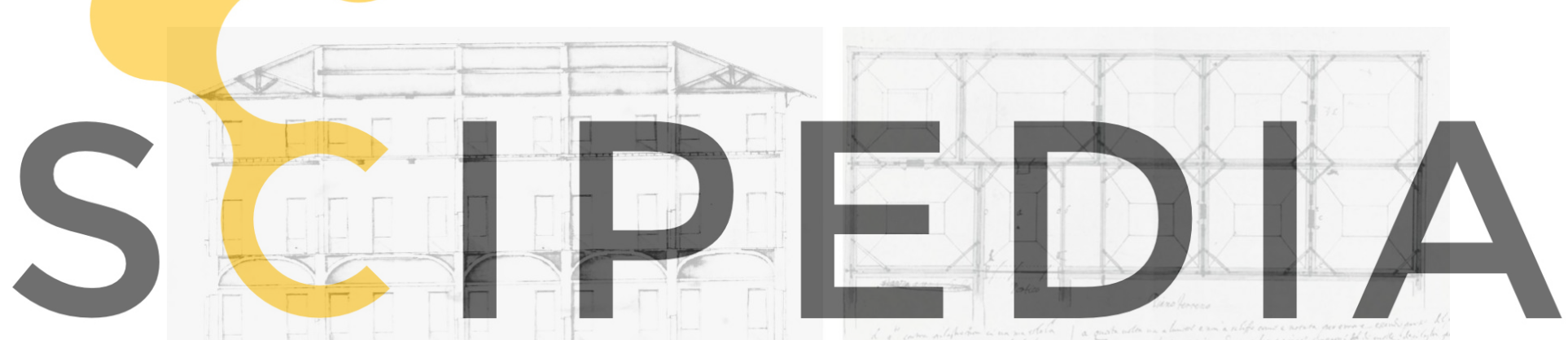

Register for free at https//www.scipedia.com to download the version without the watermark

Figure 8: Archive documents of the executive project proposed for Volpi Palace in Como dated back approximately to 1623: a) vertical section and b) plan of the ground floor with the tie beam system arranged around the vaults and inserted into vertical walls (published in [18], pp. 20-21).

The case of Volpi Palace represents an experience overpassing the physical limits of the distance between the designer and the on-site builders, but also crossing over two well defined different cultural environments, where the art of building was deeply based on local traditions [19-20]. An aspect of the physical and cultural distance between the actors involved in the building of the palace is represented by the technical lexicon found in the letters, alternatively influenced by the Roman jargon and the Lombard dialect. The timbering system is described by using two terms, "ligato" and "telaro", which seem equivalent, even if coming from slightly different semantic domains. They both mean a wooden tie-rod, or a system of tie-rods [21], used for the global firmness of the building, usually working as a passive aid. The use of timber as additional components of the masonry walls appears here as a common practice, demonstrating an advanced knowledge over the mechanical behaviour of vaulted spaces. Even if important contributes in the literature, concerning historical structures, emphasized the role 
of wooden elements as anti-seismic measure, the analyzed archive documents are showing a technical solution based on strain containment, that is described as a non-written standardized methodology.

The practice of tying the masonry walls, involved in the load distribution under the actions produced by masonry vaults, is described both by graphical drawings and written documents. The role of the timbering system surrounding the vaults is more connected to the research of the congruence of the building components more than a general response to seismic actions.

\section{CONCLUSIONS}

The use of timber elements in historical buildings knew a limited success in the Italian literature produced by the main theorists about architecture. The present study collects several examples of the application of timbering systems to the masonry building, showing a mature knowledge of the mechanical behaviour of complex structures, like vaulted spaces, requiring special attentions. The common practice of using tying beams in wooden material, described in the archive documents concerning Volpi Palace, is a useful evidence of the state of on-site practices. The common assumption that the timbering systems applied into masonry walls, as a reinforcing grid mainly connected to the response in case of seismic actions, should consider that the diffused knowledge of the mechanical properties of masonry vaults constituted a first substrate for founding the technological solutions against the vulnerability of historical buildings to seismic events.

\section{REFERENCES}

[1] Ferrigni, F. Vernacular architecture: a paradigm of the local seismic culture. In M. Correira et al. (Eds): Seismic Retrofitting Learning from Vernacular Architecture, CRC Press Balkema (2015), pp. 1-13.

[2] Touliatos, P. Coopereting Timber and Stone Antiseismic Frames in Historic Structures of Greece. In H. Cruz et al. (Eds.): Historical Earthquake-Resistant Timber Framing in the Mediterranean Area, Springer (2015), pp. 3-15.

[3] Campisi, T., Saeli, M. Timber anti-seismic devices in historical architecture in the Mediterranean area. In K. de Proft et al. (Eds): Timber Structures and Engineering, Witpress (2018), pp. 149-161.

[4] Della Torre, S. Alcune osservazioni sull'uso di incatenamenti lignei in edifici lombardi dei secoli XVI e XVII. In M. Casciato et al. (Eds.): Il modo di costruire. Atti del I Seminario Internazionale, Roma 6-8 giugno 1988, Edilstampa (1990), pp. 135-144.

[5] Cesariano. C. Di Lucio Vitruvio Pollione De architectura libri dece traducti de latino in vulgare, affigurati, comentati. Como, (1521).

[6] Viollet-le-Duc, E. E. voice Chainage in Dictionnaire raisonnè de l'architecture francaise du Xie au XVIe siècle, Tome II. De Nobele. Paris, (1868), pp. 396-404.

[7] Scamozzi, V. Dell'idea della architettura universale. Vicenza, (1714).

[8] Di Teodoro, F. P. Giovanni Poleni, Domico Maria Manni e le catene per la cupola di Santa Maria del Fiore: per la storia delle fratture e dei previsti risarcimenti alla "grande macchina di Filippo Brunelleschi”. In Annali di architettura. 23 (2011), pp. 152-177.

[9] Ottoni, F. Delle cupole e del loro tranello. Aracne, Roma, (2015).

[10] Mastrodicasa, S. Dissesti statici delle strutture edilizie. Milano, (1978). 
[11] D'Antonio, M. Ita terraemotus damna impedire. Carsa Edizioni, (2013).

[12] Varagnoli, C. Abruzzo. Un ritratto edilizio. In C. Varagnoli (Ed.): La costruzione tradizionale in Abruzzo. Fonti materiali e tecniche costruttive dalla fine del Medioevo all'Ottocento. Cangemi Editore, Roma, (2008), pp. 11-34.

[13] Varagnoli, C. Tecniche e materiali nella costruzione delle volte in Abruzzo. In C. Varagnoli (Ed.): La costruzione tradizionale in Abruzzo. Fonti materiali e tecniche costruttive dalla fine del Medioevo all'Ottocento. Cangemi Editore, Roma, (2008), pp. 49-64.

[14] Panizza, G. Pellegrino Pellegrini. L'architettura. Milano, (1990).

[15] Bartolomucci, C. Terremoti e resilienza nell'architettura aquilana. Edizioni Quasar, Roma, (2018).

[16] Campisi, T., Sibilia F. The Use of Wood with an Anti-seismic Function in the Architecture of Palermo during the 18th Century. In H. Cruz et al. (Eds.): Historical EarthquakeResistant Timber Framing in the Mediterranean Area. Springer, (2005), pp. 113-124.

[17] Montana, S. L'uso dei dispositivi di rinforzo ligneo nell'architettura siciliana di età moderna. In Lexicon. Storie e architettura in Sicilia e nel Mediterraneo. 18, (2018), pp. 32-39.

[18] Della Torre, S. Il Palazzo Volpi. In S. Della Torre (Ed.): Il mestiere di costruire. Documenti per una storia del cantiere. Il caso di Como. Nodo Libri, (1992), pp. 99-104.

[19] Scavizzi, C. P. Edilizia a Roma nei secoli XVII e XVIII. Ricerca per una storia delle tecniche. Quaderni, 6, Ministero dei Beni Culturali e Ambientali, Roma, (1983).

[20] Patetta, L. Le "catene" come scelta progettuale negli edifici tra XIII e XV secolo. In L. Patetta (Ed.): Scritti sull'architettura del Rinascimento, (2000), pp. 205-217.

[21] Pracchi, V. Tecnologia ed organizzazione edilizia nel territorio di Como: appunti e considerazioni. In S. Della Torre (Ed.): Il mestiere di costruire. Documenti per una storia del cantiere. Il caso di Como. Nodo Libri, (1992), pp. 29-48. 